\title{
Safety issues concerning the medical use of cannabis and cannabinoids
}

\author{
Mark A Ware MBBS MRCP MSc ${ }^{1,2}$, Vivianne L Tawfik BSc ${ }^{2}$
}

\begin{abstract}
MA Ware, VL Tawfik. Safety issues concerning the medical use of cannabis and cannabinoids. Pain Res Manage 2005;10(Suppl A):31A-37A.
\end{abstract}

Safety issues are a major barrier to the use of cannabis and cannabinoid medications for clinical purposes. Information on the safety of herbal cannabis may be derived from studies of recreational cannabis use, but cannabis exposure and effects may differ widely between medical and recreational cannabis users. Standardized, quality-controlled cannabinoid products are available in Canada, and safety profiles of approved medications are available through the Canadian formulary. In the present article, the evidence behind major safety issues related to cannabis use is summarized, with the aim of promoting informed dialogue between physicians and patients in whom cannabinoid therapy is being considered. Caution is advised in interpreting these data, because clinical experience with cannabinoid use is in the early stages. There is a need for long-term safety monitoring of patients using cannabinoids for a wide variety of conditions, to further guide therapeutic decisions and public policy.

Key Words: Adverse events; Cannabis/cannabinoid; Safety; Therapy

Dhysicians' concerns about the use of cannabis for medical purposes, particularly in its widely used and unregulated herbal form, are often focused on safety issues. Because herbal cannabis has been used recreationally for many years and has been extensively studied, information on the safety concerns may be obtained by extrapolating results from epidemiological studies. Safety information about medicinal cannabinoid use may also be obtained from preparations of single cannabinoid compounds, which have been approved by regulatory agencies and have been prescribed for more than 20 years. The use of cannabis by patients with diseases such as HIV/AIDS, epilepsy, chronic noncancer pain, glaucoma and multiple sclerosis gives rise to potential safety concerns that are not addressed in observational research on recreational users. Examples of such concerns are potential drug-drug interactions, alterations in the immune functions of immunocompromised patients, and the risk of developing dependency disorders when cannabis is used in a medical context.

The present paper is an overview of safety issues regarding medicinal cannabis use. The aim is to promote a meaningful and informed dialogue between patients and health care providers regarding cannabis use.

\section{Innocuité du cannabis et des cannabinoïdes utilisés à des fins médicales}

Les problèmes d'innocuité représentent un obstacle de taille à l'utilisation du cannabis et des médicaments dérivés des cannabinoïdes à des fins cliniques. Les données d'innocuité relatives à l'utilisation de la plante peuvent en effet provenir d'études sur l'utilisation du cannabis à des fins récréatives. Or, l'exposition au cannabis et ses effets peuvent différer considérablement selon que les utilisateurs le consomment à des fins médicales ou récréatives. Au Canada, on trouve des produits dérivés des cannabinoïdes standardisés et soumis à un contrôle de la qualité et les profils d'innocuité des médicaments approuvés peuvent être consultés par l'entremise du Formulaire canadien. Dans le présent article, l'auteur offre un résumé des principaux enjeux liés à l'innocuité du cannabis dans le but de favoriser un dialogue éclairé entre médecins et patients chez qui on envisage un traitement par cannabinoïdes. La prudence s'impose lorsque l'on interprète les données de la recherche clinique, puisque l'expérience pratique avec les cannabinoïdes en est à ses débuts. Il faudra exercer une surveillance à long terme de l'innocuité des cannabinoïdes chez les patients atteints de divers problèmes de santé pour mieux orienter les décisions thérapeutiques et les politiques en matière de réglementation.

\footnotetext{
${ }^{1}$ Montreal General Hospital; ${ }^{2}$ McGill University, Montreal, Quebec

Correspondence: Dr Mark Ware, E19.145 Montreal General Hospital, 1650 Cedar Avenue, Montreal, Quebec H3G 1A4.

Telephone 514-934-8222 ext 4386, fax 514-934-8096, e-mail mark.ware@muhc.mcgill.ca
} 
TABLE 1

Incidence of adverse events of regulated cannabinoids: Probable causal relationships with incidences of greater than $1 \%$

\begin{tabular}{lcc}
\hline Adverse event & Dronabinol (\%) & Nabilone (\%) \\
\hline 'High' & $8-24$ & 38.8 \\
Somnolence & $3-10$ & 66 \\
Dizziness & $3-10$ & 58.8 \\
Dry mouth & & 21.6 \\
Euphoria & $3-10$ & 4.0 \\
Paranoid reaction & $3-10$ & \\
Nausea & $3-10$ & \\
Abdominal pain & $3-10$ & \\
Thinking abnormalities/confusion & $3-10$ & \\
Ataxia & $>1$ & 12.8 \\
Asthenia & $>1$ & 7.6 \\
Amnesia & $>1$ & \\
Anxiety/nervousness & $>1$ & \\
Depersonalization & $>1$ & \\
Vomiting & $>1$ & \\
Palpitations & $>1$ & \\
Tachycardia & $>1$ & \\
Vasodilation/facial flush & $>1$ & \\
Blurred vision & & \\
Sensation disturbance & & \\
Anorexia & & \\
Headache & & \\
Orthostatic hypertension & & \\
Hallucinations & & \\
\hline Data from refer. & \\
\hline & & \\
\hline & & \\
\hline
\end{tabular}

Data from reference 1

\section{RESULTS}

One hundred fifty-seven papers were identified from the literature search for adverse effects, of which 79 were felt to be of relevance. The product monographs for nabilone and dronabinol were obtained.

\section{Cannabinoid-based drugs}

A summary of the adverse event profiles obtained from the 2004 Compendium of Pharmaceuticals and Specialties (1) for dronabinol and nabilone are provided in Table 1 . The most commonly reported adverse events are a 'high', drowsiness, dizziness and dry mouth. For further information, refer to the product monographs of these drugs $(2,3)$.

\section{Herbal cannabis}

Herbal cannabis is most often smoked. Survey data suggest that patients with chronic pain smoke between one and four puffs from a cannabis joint two to three times a day (4) (although larger doses are also known to be used by some patients). The exposures reported in recreational epidemiological and experimental studies range widely, from single exposures to over 20 years of daily heavy cannabis use.

The major safety concerns may be divided into those about the quality of the product and those about the administration of the drug itself. Drug administration effects are further divided into effects related to the delivery system and effects directly related to the cannabinoid compounds.
Quality concerns
Adverse events due to the use of contaminated cannabis were reported only in cannabis smokers. Contamination with Aspergillus has given rise to concerns of lung infections in immunocompromised patients (5-7). Contamination with paraquat (a potent pesticide) has not been associated with adverse effects (8). Contamination with formaldehyde has been reported to impair memory (9) and may be life threatening (10). Cannabis soaked in embalming fluid has been reported to cause phencyclidine-like responses (11).

The sharing of cannabis with contaminated smoking paraphernalia has been associated with small outbreaks of tuberculosis (12) and meningococcal disease $(13,14)$.

\section{Safety concerns related to cannabis smoking: Respiratory} function

Cannabis smoking poses a potential health risk. Cannabis smoke has been shown to have qualitatively the same constitution as tobacco smoke but with quantitatively higher concentrations of polyaromatic hydrocarbons, which are known carcinogens (15). Cannabis smoke, like tobacco smoke, contains carbon monoxide, which preferentially binds hemoglobin at the expense of oxygen binding.

A higher prevalence of chronic bronchitis symptoms, such as cough, phlegm and wheeze, has also been noted in cannabis smokers (16-19). All symptoms were most evident in heavy, chronic users, defined as those who had smoked more than three joints per day for 25 years or more. There is a published report (20) of four cases of emphysema in adults with a history of cannabis smoking. However, observational surveys of heavy, chronic cannabis use have failed to find any lung damage in long-term smokers (21). Pneumomediastinum and pneumothorax have been reported following the prolonged Valsalva manoeuvre that may accompany cannabis smoking (possibly through rupturing emphysematous bullae) (22-25).

Several case studies of young patients with carcinoma of the upper respiratory tract have been published (26). There is concern that heavy cannabis smoking is a causative factor of this type of cancer, which is rare in adults under the age of 60 years, even in those who smoke tobacco and drink alcohol $(27,28)$. One case-control study (29) reported an increased risk of upper respiratory tract cancer due to cannabis smoking; however, two recent case-control studies $(30,31)$ have failed to find any increased risk of oral squamous cell cancers due to cannabis smoking. No association between cannabis smoking and tobacco smoking-related cancers was found in a large retrospective cohort study (32).

The effects of exposure to cannabis smoke in low doses in patients using cannabis therapeutically have not been determined. The doses used by patients for symptom relief may be low, and risks increase with heavy, chronic use of cannabis.

\section{Acute effects}

Mood effects: Acute reactions, such as nausea, anxiety, paranoia and disorientation often occur in new cannabis users but are uncommon in regular cannabis users (33). Many patients were considered to be asymptomatic after abstinence from cannabis for four months (34). For patients seeking symptom relief, the psychological high associated with cannabis smoke inhalation may be another unwanted effect, but this moodaltering effect may be an important part of the overall therapeutic response. Euphoria, altered time perception and 
relaxation are acute reactions that disappear within $3 \mathrm{~h}$ to $4 \mathrm{~h}$ and are considered part of the high (35).

Acute toxicity: Unlike opioids, cannabis does not cause central respiratory depression (36). Acute hyperthermia has been reported following cannabis use and jogging on a warm day (37). Overdosing is extremely rare and is usually accompanied by the use of other drugs, such as alcohol. A lethal tetrahydrocannabinol (THC) dose has not been reported. From a purely pharmacological perspective, cannabinoids appear to be very safe. For a more detailed review of toxicity, please see the article by Beaulieu (pages 23A-26A). Doctors at the HaightAshbury clinic in the San Francisco Bay area who work primarily with drug addicts have stated that it is virtually impossible to die of a cannabis overdose (33).

Anxiety and panic: Acute anxiety and panic are recognized as possible complications of cannabis use, usually in the new user $(35,38)$. Patients usually respond to reassurance. Cannabis use in a relaxed and supportive atmosphere may help reduce anxiety. In addition, patients appreciate being made aware of likely psychoactive effects on first doses, and gradual titration to an effective dose may promote tolerance to adverse psychoactive effects. Some subjects may find the anxiety unpleasant enough to stop using cannabis. Feelings of paranoia have been observed among recreational users with bipolar and panic disorders (39). The illegal status of the drug may be an important confounder in this regard.

Cardiac and other vascular effects: The cardiovascular effects of cannabis were recently reviewed (40). An increased relative risk of nonfatal myocardial infarction in the first hour following cannabis smoking has been described (41). Myocardial infarction following cannabis use and Viagra (Pfizer Canada Inc) consumption has been reported (42). The increase in heart rate following cannabis use may play a role by increasing myocardial oxygen demand, but other factors, such as plaque rupture and arrhythmias, may also have an effect (43-45).

Cannabis smoking-induced tachycardia may be problematic for patients with comorbid ischemic heart disease or arrhythmias. It has been found that inhalation of cannabis smoke reduces the amount of exercise required to cause an attack of angina by $50 \%$ (46). Cannabis-induced tachycardia is reduced by clonidine, an alpha-2 agonist, which suggests that THC may play a role in sympathetic nervous system stimulation (47), although a reduction in parasympathetic tone has also been suggested (48).

Cannabis is known to cause postural hypotension immediately after smoking (49). It also causes peripheral vasodilation, resulting in characteristic conjunctival reddening. It is plausible that the increased heart rate and drop in blood pressure may be secondary to a drop in peripheral vascular resistance. In addition, antiretroviral therapy (ie, highly active antiretroviral therapy) has been shown to cause lipid abnormalities in patients with HIV/AIDS. These lipid abnormalities may result in an increased risk for ischemic heart disease, which could be exacerbated by cannabis (50).

Transient ischemic attacks (51) and cerebrovascular stroke, usually following acute cannabis use, have also been reported in several case reports (52-56). Renal infarction following cannabis smoking has also been reported (57).

Cognitive function: Impaired performance has been observed using the circular lights test after subjects smoked two cannabis cigarettes containing $2.8 \%$ THC (58). A slight slowing of reaction was found by using digit symbol substitution and automated tracking tests after three doses of $0 \%, 1.3 \%$ and $2.7 \%$ THC. Inhalation of cannabis smoke had no effect on performance in the divided attention task (59). Performance measures have shown no dose-related effects on reaction times, but a doseresponse effect on accuracy has been observed (60). Acute cannabis exposure has been associated with a hangover or residual effect on psychomotor performance $(61,62)$.

Effects on driving: The literature concerning the risks of cannabis and driving is controversial, and no studies have been published on the effects of medicinal cannabis use on driving. The results are often influenced by the confounding effects of alcohol. Cannabis is known to cause mild euphoria, altered time perception and decreased motor coordination, which affect driving skills. Studies (63) have found that perceptual motor speed and accuracy are impaired after smoking a cannabis joint. However, it has been suggested that, unlike users of alcohol, cannabis users are aware of their level of intoxication and compensate for the effects by becoming very cautious, resulting in a decrease in the speed and the frequency of overtaking, as well as an increase in the following distance (64). It is recognized that cannabis may have significant effects on driving ability, with exaggerated effects in the presence of alcohol (65).

Seizures: Data on the risk of epileptic seizures following cannabis use were nonconclusive (66).

\section{Long-term effects}

Dependency: The risk of cannabis dependency is an important consideration when contemplating its medical use. In the present supplement, this is discussed further by Gourlay (pages 38A43A). Although dependence on cannabis has been described, it is difficult to quantify the extent of this risk. Cannabis has a lower rate of conditional dependence (the risk of developing dependence among those who have used the drug) than alcohol, cocaine, heroin or tobacco, although the rate increases with the amount used (67). Substance abuse rarely begins with therapeutic use alone, as the experience with opioid analgesics has shown (68). Withdrawal symptoms such as cravings, irritability, anxiety, depression, reduced appetite and poor sleep after withdrawal from oral THC and smoked cannabis have been described (69-71), but the symptoms are limited to heavy, chronic users and are relatively short lived (72).

The abuse potential of nabilone (73) and dronabinol (74) have been examined and there is no published evidence that these drugs are prone to abuse or diversion (however, see the article by Gourlay). Long-term monitoring data on addictive behaviours are needed.

Cognitive function: The effects of long-term cannabis use on cognitive function remain controversial $(75,76)$. In chronic users (10 to 15 years), cognitive impairments, such as deficits in memory of word lists, compared with nonusers are observed, but these resolve after 30 days of abstinence and may be related to acute effects (77). A meta-analysis (78) of the residual neurocognitive effects of cannabis use reported decreases in the performance of memory tasks. A recent study (79) suggested that patients with advanced HIV/AIDS may be at risk for aggravated memory impairment due to cannabis use. The long-term effects of cannabis use on neurocognitive function may be due to a direct effect of cannabis use or may be due to confounding effects (80); further research is required to draw conclusions.

Drug interactions: THC and other cannabinoids are metabolized by enzymes that are also responsible for the metabolism of 


\section{COPYRIGHT PULSUS GROUP INC, " DO NOT COPY}

commonly prescribed medicines. This may potentially result in important drug-drug interactions. At least two cytochrome (CY) P450 enzyme systems, CYP2C and CYP3A, have been shown to be involved in the metabolism of cannabinoids (81). Recently, it was found that although delta-9-THC and antiretroviral drugs are metabolized by CYP3A, administration of THC (smoked or orally) does not significantly reduce plasma concentrations of antiretroviral drugs in patients with HIV/AIDS (82). Potential interactions with tricyclic antidepressants have been reported (83-85), but a conclusive link has not been established.

Immunity: It is apparent that delta-9-THC has immunomodulating effects, but the related health risks are not well defined. The dose required to obtain such effects is greater than that required for psychoactive or therapeutic effects (86). In a randomized, double-blind study of the effects of smoked cannabis (3.95\% THC, $1 \mathrm{~g}$ three times daily) and oral THC $(2.5 \mathrm{mg}$ three times daily) administered over 21 days in patients with HIV/AIDS, neither the smoked nor the oral THC had a significant effect on CD4 cell counts or viral loads compared with placebo (82).

Nausea and vomiting: A recent case series (87) described a cyclical vomiting syndrome associated with chronic, heavy cannabis use ('cannabinoid hyperemesis'), which was linked to an abnormal washing behaviour.

Psychological effects: While cannabis use is associated with depression (88) and anxiety (89), a causative link has not been established. A recent systematic review (90) did not find a strong association between chronic cannabis use in young people and psychosocial harm.

Long-term cognitive effects: The presence of long-term cognitive effects following chronic, heavy use has been shown $(75,78)$, particularly in the domains of memory and learning, and there is debate over whether these effects are reversible $(91,92)$. Under medical use conditions, the relevance of these effects has been questioned (78).

Psychosis and schizophrenia: An association between cannabis use and an increased risk of psychosis and schizophrenia has been reported (93). In a study by Zammit et al (93), cannabis use was found to be a risk factor for developing schizophrenia (in a dose-dependent manner). Cannabis has also been shown to be associated with a schizotypal personality disorder (94), but the direction of this association is unclear. Cannabis has been shown to be a risk factor in the development of psychotic symptoms in young people, particularly among those with a predisposition for psychosis (95). Recent modelling studies (96) have suggested that daily cannabis use is causally associated with the development of psychosis. 'Cannabis psychosis' (97) has been shown to be clinically distinct from acute schizophrenia, with a shorter duration and high rates of remission (98); however, one report (99) has questioned the existence of cannabis psychosis disorder. A recent retrospective study (100) and a review (101) have confirmed the association between cannabis use and precipitation of schizophrenia in predisposed people and in people without a history of schizophrenia.

Effects on pregnancy: The effects of cannabis on the reproductive system in humans are uncertain because the published evidence is limited and inconsistent (35). Results from human epidemiological studies are difficult to interpret because cannabis users are more likely than nonusers to smoke tobacco, drink alcohol and use other illicit drugs during pregnancy.
Cannabis use during pregnancy has been correlated with low birth weight $(102,103)$, prematurity (104) and intrauterine growth retardation (105), although contradictory findings have also been reported (106). Frequent maternal cannabis use may be a weak risk factor for sudden infant death syndrome (107).

Risk of death: In one large retrospective cohort study of patients with HIV/AIDS (108), current cannabis use was not associated with an increased risk of non-AIDS death in men ( $\mathrm{RR}=1.72,95 \%$ CI 0.89 to 1.39 ); however, it was associated with an increased risk of AIDS-related death $(R R=1.90$, $95 \%$ CI 1.33 to 2.73 ) when compared with nonusers and experimental users of cannabis. For women, current cannabis use was not associated with total mortality $(\mathrm{RR}=1.09,95 \% \mathrm{CI}$ 0.80 to 1.49 ) (107). It is not clear whether the use of cannabis was causally related to AIDS-related mortality or whether cannabis smoking was used to treat worsening symptoms and was a confounder in this analysis.

Vascular effects: Peripheral arteritis, which is analogous to Buerger's disease in tobacco smokers, has been reported in several case reports $(109,110)$.

\section{DISCUSSION}

The use of cannabis in any form poses potential health risks that are well described (although some remain controversial). Cannabis smoking clearly poses unique risks, both from the smoke and from potential contamination. The use of standardized and quality-controlled cannabis preparations with accurate monitoring and follow-up may identify and reduce these risks. The use of pharmaceutical cannabis preparations has risks that are well documented on product labels, but further research is required on the long-term effects of these products. The safety of cannabinoids in children, the elderly and patients with comorbid disorders (eg, diabetes, hypertension, ischemic heart disease, renal and hepatic impairment, and diseases that damage the immune system), as well as the effects of cannabinoid use on concurrent psychiatric illness (eg, depression, anxiety, psychosis and drug abuse) are all subjects for further research.

Some broad clinical recommendations based on existing safety information may be put forward, but these must be continuously revised as new data are published. Patients with a history of a psychotic disorder such as schizophrenia should not use cannabis. The use of cannabis during pregnancy should be avoided. Patients with uncontrolled hypertension and active ischemic heart disease should avoid cannabis. Patients using cannabis therapeutically should not drive or operate heavy machinery while experiencing the psychoactive effects of cannabis (consistent with advice concerning the therapeutic use of other psychoactive agents such as benzodiazepines and opioids). Patients with comorbid depression and other psychiatric disorders should be carefully monitored. Cannabinoids should be administered initially at low doses and titrated slowly to balance the positive and negative acute effects. Patients should be advised of the nature and likelihood of acute effects, and close monitoring is advised during the initial dose titration.

Most of our current knowledge about the risks of herbal cannabis is derived from studies of recreational users, and these risks may or may not be relevant in a medical use paradigm. The doses used may be different, the psychoactive effects at therapeutic doses may have a different impact, and the total lifetime exposure may be different. A considerable cumulative dose response to cannabinoids has been observed in many 
areas and, therefore, some risks apply only to those who use cannabis over a long period of time.

\section{CONCLUSIONS}

Cannabis is used by many patients with a wide range of chronic disorders. Canadian physicians are being asked to support patient applications for authorizations to cultivate and possess cannabis for medical purposes. Physicians need to be able to provide a concise summary of known or suspected risks to their patients. It is hoped that this review will be a useful tool in this regard.

\section{SUGGESTED FURTHER READING}

- Zimmer L, Morgan JP. Marijuana Myths, Marijuana Facts: A Review of the Scientific Evidence. New York: Lindesmith Centre, 1997.

- Joy JE, Watson SJ, Benson JA, eds. Marijuana and Medicine: Assessing the Science Base. Institute of Medicine report. Washington: National Academy Press, 1999.

- Iversen LL. The Science of Marijuana. Oxford: Oxford University Press, 2000.

- Castle D, Murray R, eds. Marijuana and Madness. Cambridge: Cambridge University Press, 2004.

- Grinspoon L, Bakalar JB. Marijuana: The Forbidden Medicine. New Haven: Yale University Press, 1997.

SUPPORT: Dr Mark Ware is supported by the fonds de la recherche en santé (Boursier-clinicien junior 1) and holds grants from the Canadian Institutes of Health Research. He has received honoraria from Valeant and AstraZeneca, has sat on advisory boards for Bayer and Valeant, has acted as a consultant to Cannasat, and has conducted research with grants from GW Pharmaceuticals and Valeant.

\section{REFERENCES}

1. Compendium of Pharmaceuticals and Specialties. Ottawa: Canadian Pharmacists Association, 2004.

2. Product monograph: Marinol. <www.solvaypharma.ca/en/ products/HCP/Marinol.asp > (Version current at June 29, 2005).

3. Cesamet product monograph. In: CPS: Compendium of Pharmaceuticals and Specialties. Ottawa: Canadian Pharmacists Association, 2004:409-10.

4. Ware MA, Gamsa A, Persson J, Fitzcharles MA. Cannabis for chronic pain: Case series and implications for clinicians. Pain Res Manage 2002;7:95-9.

5. Hamadeh R, Ardehali A, Locksley RM, York MK. Fatal aspergillosis associated with smoking contaminated marijuana, in a marrow transplant recipient. Chest 1988;94:432-3.

6. Marks WH, Florence L, Lieberman J, et al. Successfully treated invasive pulmonary aspergillosis associated with smoking marijuana in a renal transplant recipient. Transplantation 1996;61:1771-4.

7. Szyper-Kravitz M, Lang R, Manor Y, Lahav M. Early invasive pulmonary aspergillosis in a leukemia patient linked to aspergillus contaminated marijuana smoking. Leuk Lymphoma 2001;42:1433-7.

8. Landrigan PJ, Powell KE, James LM, Taylor PR. Paraquat and marijuana: Epidemiologic risk assessment. Am J Public Health 1983;73:784-8.

9. Hawkins KA, Schwartz-Thompson J, Kahane AI. Abuse of formaldehyde-laced marijuana may cause dysmnesia. J Neuropsychiatry Clin Neurosci 1994;6:67.

10. Nelson LS, Holland JA, Ravikumar PR. Dangerous form of marijuana. Ann Emerg Med 1999;34:115-6.

11. Holland JA, Nelson L, Ravikumar PR, Elwood WN. Embalming fluid-soaked marijuana: New high or new guise for PCP? J Psychoactive Drugs 1998;30:215-9.

12. Munckhof WJ, Konstantinos A, Wamsley M, Mortlock M, Gilpin C. A cluster of tuberculosis associated with use of a marijuana water pipe. Int J Tuberc Lung Dis 2003;7:860-5.
13. Finn R, Groves C, Coe M, Pass M, Harrison LH. Cluster of serogroup $\mathrm{C}$ meningococcal disease associated with attendance at a party. South Med J 2001;94:1192-4.

14. Krause G, Blackmore C, Wiersma S, et al. Marijuana use and social networks in a community outbreak of meningococcal disease. South Med J 2001;94:482-5.

15. Hoffmann D, Brunnemann KD, Gori GB, Wynder EL. On the carcinogenicity of marijuana smoke. Recent Adv Phytochem 1975;9:63-81.

16. Bloom JW, Kaltenborn WT, Paoletti P, Camilli A, Lebowitz MD. Respiratory effects of non-tobacco cigarettes. Br Med J (Clin Res Ed) 1987;295:1516-8.

17. Tashkin DP, Coulson AH, Clark VA, et al. Respiratory symptoms and lung function in habitual heavy smokers of marijuana alone, smokers of marijuana and tobacco, smokers of tobacco alone, and nonsmokers. Am Rev Respir Dis 1987;135:209-16.

18. Barsky SH, Roth MD, Kleerup EC, Simmons M, Tashkin DP. Histopathologic and molecular alterations in bronchial epithelium in habitual smokers of marijuana, cocaine, and/or tobacco. J Natl Cancer Inst 1998;90:1198-205.

19. Sherrill DL, Krzyzanowski M, Bloom JW, Lebowitz MD. Respiratory effects of non-tobacco cigarettes: a longitudinal study in general population. Int J Epidemiol 1991;20:132-7.

20. Johnson MK, Smith RP, Morrison D, Laszlo G, White RJ. Large lung bullae in marijuana smokers. Thorax 2000;55:340-2.

21. Cruickshank EK. Physical assessment of 30 chronic cannabis users and 30 matched controls. Ann N Y Acad Sci 1976;282:162-7.

22. Birrer RB, Calderon J. Pneumothorax, pneumomediastinum, and pneumopericardium following Valsalva's maneuver during marijuana smoking. NY State J Med 1984;84:619-20.

23. Okereke UN, Weber BE, Israel RH. Spontaneous pneumomediastinum in an 18-year-old black Sudanese high school student. J Natl Med Assoc 1999;91:357-9.

24. Hazouard E, Koninck JC, Attucci S, Fauchier-Rolland F, Brunereau L, Diot P. Pneumorachis and pneumomediastinum caused by repeated Muller's maneuvers: Complications of marijuana smoking. Ann Emerg Med 2001;38:694-7.

25. Feldman AL, Sullivan JT, Passero MA, Lewis DC. Pneumothorax in polysubstance-abusing marijuana and tobacco smokers: Three cases. J Subst Abuse 1993;5:183-6.

26. Endicott JN, Skipper P, Hernandez L. Marijuana and head and neck cancer. Adv Exp Med Biol 1993;335:107-13.

27. Taylor FM III. Marijuana as a potential respiratory tract carcinogen: A retrospective analysis of a community hospital population. South Med J 1988;81:1213-6.

28. Donald PJ. Marijuana smoking - possible cause of head and neck carcinoma in young patients. Otolaryngol Head Neck Surg 1986;94:517-21.

29. Zhang ZF, Morgenstern H, Spitz MR, et al. Marijuana use and increased risk of squamous cell carcinoma of the head and neck. Cancer Epidemiol Biomarkers Prev 1999;8:1071-8.

30. Llewellyn CD, Linklater K, Bell J, Johnson NW, Warnakulasuriya S. An analysis of risk factors for oral cancer in young people: A case-control study. Oral Oncol 2004;40:304-13.

31. Rosenblatt KA, Daling JR, Chen C, Sherman KJ, Schwartz SM. Marijuana use and risk of oral squamous cell carcinoma. Cancer Res 2004;64:4049-54.

32. Sidney S, Quesenberry CP Jr, Friedman GD, Tekawa IS. Marijuana use and cancer incidence (California, United States). Cancer Causes Control 1997;8:722-8.

33. Smith DE, Mehl C. An analysis of marijuana toxicity. Clin Toxicol 1970;3:101-15.

34. Kolansky H, Moore WT. Toxic effects of chronic marihuana use. JAMA 1972;222:35-41.

35. Hall W, Solowij N. Adverse effects of cannabis. Lancet 1998;352:1611-6.

36. Vachon L, FitzGerald MX, Solliday NH, Gould IA, Gaensler EA Single-dose effects of marihuana smoke. Bronchial dynamics and respiratory-center sensitivity in normal subjects. N Engl J Med 1973;288:985-9.

37. Walter FG, Bey TA, Ruschke DS, Benowitz NL. Marijuana and hyperthermia. J Toxicol Clin Toxicol 1996;34:217-21.

38. Strohle A, Muller M, Rupprecht R. Marijuana precipitation of panic disorder with agoraphobia. Acta Psychiatr Scand 1998;98:254-5.

39. Seibyl JP, Krystal JH, Charney DS. Marijuana (cannabis) use is anecdotally said to precipitate anxiety symptoms in patients with 
panic disorder. Is there any research evidence to support this? Also, can marijuana use precipitate or expose paranoia in patients with an underlying bipolar disorder? J Clin Psychopharmacol 1990;10:78.

40. Sidney S. Cardiovascular consequences of marijuana use. J Clin Pharmacol 2002;42(Suppl 11):64S-70S.

41. Mittleman MA, Lewis RA, Maclure M, Sherwood JB, Muller JE. Triggering myocardial infarction by marijuana. Circulation 2001;103:2805-9

42. McLeod AL, McKenna CJ, Northridge DB. Myocardial infarction following the combined recreational use of Viagra and cannabis. Clin Cardiol 2002;25:133-4.

43. Kosior DA, Filipiak KJ, Stolarz P, Opolski G. Paroxysmal atrial fibrillation following marijuana intoxication: A two-case report of possible association. Int J Cardiol 2001;78:183-4.

44. Rezkalla SH, Sharma P, Kloner RA. Coronary no-flow and ventricular tachycardia associated with habitual marijuana use. Ann Emerg Med 2003;42:365-9.

45. Bachs L, Morland H. Acute cardiovascular fatalities following cannabis use. Forensic Sci Int 2001;124:200-3.

46. Aronow WS, Cassidy J. Effect of marihuana and placebo-marihuana smoking on angina pectoris. N Engl J Med 1974;291:65-7.

47. Cone EJ, Welch P, Lange WR. Clonidine partially blocks the physiologic effects but not the subjective effects produced by smoking marijuana in male human subjects. Pharmacol Biochem Behav 1988;29:649-52.

48. Newlin DB, Pretorius MB, Wong CJ, Dax EM. Acute marijuana smoking reduces vagal tone. NIDA Res Monogr 1991;105:565-6.

49. Merritt JC, Cook CE, Davis KH. Orthostatic hypotension after delta 9-tetrahydrocannabinol marihuana inhalation. Ophthalmic Res 1982;14:124-8.

50. Purnell JQ, Zambon A, Knopp RH, et al. Effect of ritonavir on lipids and post-heparin lipase activities in normal subjects. AIDS 2000;14:51-7.

51. Mouzak A, Agathos P, Kerezoudi E, Mantas A, Vourdeli-Yiannakoura E. Transient ischemic attack in heavy cannabis smokers-how 'safe' is it? Eur Neurol 2000;44:42-4.

52. Cooles P, Michaud R. Stroke after heavy cannabis smoking. Postgrad Med J 1987;63:511.

53. Zachariah SB. Stroke after heavy marijuana smoking. Stroke 1991;22:406-9

54. White D, Martin D, Geller T, Pittman T. Stroke associated with marijuana abuse. Pediatr Neurosurg 2000;32:92-4.

55. Finsterer J, Christian P, Wolfgang K. Occipital stroke shortly after cannabis consumption. Clin Neurol Neurosurg 2004;106:305-8.

56. Geller T, Loftis L, Brink DS. Cerebellar infarction in adolescent males associated with acute marijuana use. Pediatrics 2004;113:e365-70.

57. Lambrecht GL, Malbrain ML, Coremans P, Verbist L, Verhaegen H. Acute renal infarction and heavy marijuana smoking. Nephron 1995;70:494-6.

58. Cone EJ, Johnson RE, Moore JD, Roache JD. Acute effects of smoking marijuana on hormones, subjective effects and performance in male human subjects. Pharmacol Biochem Behav 1986;24:1749-54.

59. Heishman SJ, Stitzer ML, Yingling JE. Effects of tetrahydrocannabinol content on marijuana smoking behavior, subjective reports, and performance. Pharmacol Biochem Behav 1989;34:173-9.

60. Chait LD, Corwin RL, Johanson CE. A cumulative dosing procedure for administering marijuana smoke to humans. Pharmacol Biochem Behav 1988;29:553-7.

61. Chait LD, Fischman MW, Schuster CR. 'Hangover' effects the morning after marijuana smoking. Drug Alcohol Depend 1985;15:229-38.

62. Chait LD. Subjective and behavioral effects of marijuana the morning after smoking. Psychopharmacology (Berl) 1990;100:328-33.

63. Kurzthaler I, Hummer M, Miller C, et al. Effect of cannabis use on cognitive functions and driving ability. J Clin Psychiatry 1999;60:395-9.

64. Gieringer DH. Marijuana, driving, and accident safety. J Psychoactive Drugs 1988;20:93-101.

65. O'Kane CJ, Tutt DC, Bauer LA. Cannabis and driving: A new perspective. Emerg Med (Fremantle) 2002;14:296-303.

66. Gordon E, Devinsky O. Alcohol and marijuana: Effects on epilepsy and use by patients with epilepsy. Epilepsia 2001;42:1266-72.

67. Budney AJ, Moore BA. Development and consequences of cannabis dependence. J Clin Pharmacol 2002;42(Suppl 11):28S-33S.

68. Moulin DE, Iezzi A, Amireh R, Sharpe WK, Boyd D, Merskey H. Randomised trial of oral morphine for chronic non-cancer pain. Lancet 1996;347:143-7.
69. Haney M, Ward AS, Comer SD, Foltin RW, Fischman MW. Abstinence symptoms following smoked marijuana in humans. Psychopharmacology (Berl) 1999;141:395-404.

70. Haney M, Ward AS, Comer SD, Foltin RW, Fischman MW. Abstinence symptoms following oral THC administration to humans. Psychopharmacology (Berl) 1999;141:385-94.

71. Kouri EM, Pope HG Jr. Abstinence symptoms during withdrawal from chronic marijuana use. Exp Clin Psychopharmacol 2000;8:483-92.

72. Smith NT. A review of the published literature into cannabis withdrawal symptoms in human users. Addiction 2002;97:621-32.

73. Lemberger L, Rubin A, Wolen R, et al. Pharmacokinetics, metabolism and drug-abuse potential of nabilone. Cancer Treat Rev 1982;9(Suppl B):17-23

74. Calhoun SR, Galloway GP, Smith DE. Abuse potential of dronabinol (Marinol). J Psychoactive Drugs 1998;30:187-96.

75. Solowij N, Stephens RS, Roffman RA, et al. Cognitive functioning of long-term heavy cannabis users seeking treatment. JAMA 2002;287:1123-31.

76. Pope HG Jr. Cannabis, cognition, and residual confounding. JAMA 2002;287:1172-4.

77. Pope HG Jr, Gruber AJ, Hudson JI, Huestis MA, Yurgelun-Todd D. Neuropsychological performance in long-term cannabis users. Arch Gen Psychiatry 2001;58:909-15.

78. Grant I, Gonzalez R, Carey CL, Natarajan L, Wolfson T. Non-acute (residual) neurocognitive effects of cannabis use: A meta-analytic study. J Int Neuropsychol Soc 2003;9:679-89.

79. Cristiani SA, Pukay-Martin ND, Bornstein RA. Marijuana use and cognitive function in HIV-infected people. J Neuropsychiatry Clin Neurosci 2004;16:330-5.

80. Pope HG Jr, Yurgelun-Todd D. Residual cognitive effects of longterm cannabis use. In: Castle DJ, Murray R, eds. Marijuana and Madness. Cambridge: Cambridge University Press, 2003:198-210.

81. Yamamoto I, Watanabe K, Narimatsu S, Yoshimura H. Recent advances in the metabolism of cannabinoids. Int J Biochem Cell Biol 1995;27:741-6.

82. Abrams DI, Hilton JF, Leiser RJ, et al. Short-term effects of cannabinoids in patients with HIV-1 infection: A randomized, placebo-controlled clinical trial. Ann Intern Med 2003;139:258-66.

83. Hillard JR, Vieweg WV. Marked sinus tachycardia resulting from the synergistic effects of marijuana and nortriptyline. Am J Psychiatry 1983;140:626-7.

84. Wilens TE, Biederman J, Spencer TJ. Case study: Adverse effects of smoking marijuana while receiving tricyclic antidepressants. J Am Acad Child Adolesc Psychiatry 1997;36:45-8

85. Mannion V. Case report: Adverse effects of taking tricyclic antidepressants and smoking marijuana. Can Fam Physician 1999;45:2683-4.

86. Klein TW, Friedman H, Specter S. Marijuana, immunity and infection. J Neuroimmunol 1998;83:102-15.

87. Allen JH, de Moore GM, Heddle R, Twartz JC. Cannabinoid hyperemesis: Cyclical hyperemesis in association with chronic cannabis abuse. Gut 2004;53:1566-70.

88. Green BE, Ritter C. Marijuana use and depression. J Health Soc Behav 2000;41:40-9.

89. Patton GC, Coffey C, Carlin JB, Degenhardt L, Lynskey M, Hall W. Cannabis use and mental health in young people: Cohort study. BMJ 2002;325:1195-8.

90. Macleod J, Oakes R, Copello A, et al. Psychological and social sequelae of cannabis and other illicit drug use by young people: A systematic review of longitudinal, general population studies. Lancet 2004;363:1579-88.

91. Harrison GP Jr, Gruber AJ, Hudson JI, Huestis MA, Yurgelun-Todd D. Cognitive measures in long-term cannabis users. J Clin Pharmacol 2002;42(Suppl 11):41S-7S.

92. Solowij N. Do cognitive impairments recover following cessation of cannabis use? Life Sci 1995;56:2119-26.

93. Zammit S, Allebeck P, Andreasson S, Lundberg I, Lewis G. Self reported cannabis use as a risk factor for schizophrenia in Swedish conscripts of 1969: Historical cohort study. BMJ 2002;325:1199.

94. Williams JH, Wellman NA, Rawlins JN. Cannabis use correlates with schizotypy in healthy people. Addiction 1996;91:869-77.

95. Henquet C, Krabbendam L, Spauwen J, et al. Prospective cohort study of cannabis use, predisposition for psychosis, and psychotic symptoms in young people. BMJ 2005;330:11.

96. Fergusson DM, Horwood LJ, Ridder EM. Tests of causal linkages between cannabis use and psychotic symptoms. Addiction 2005;100:354-66 
97. Bartolucci G, Fryer L, Perris C, Shagass C. Marijuana psychosis: A case report. Can Psychiatr Assoc J 1969;14:77-9.

98. Basu D, Malhotra A, Bhagat A, Varma VK. Cannabis psychosis and acute schizophrenia. A case-control study from India. Eur Addict Res 1999;5:71-3.

99. McGuire PK, Jones P, Harvey I, et al. Cannabis and acute psychosis. Schizophr Res 1994;13:161-7.

100. van Os J, Bak M, Hanssen M, Bijl RV, de Graaf R, Verdoux H. Cannabis use and psychosis: A longitudinal population-based study. Am J Epidemiol 2002;156:319-27.

101. Smit F, Bolier L, Cuijpers P. Cannabis use and the risk of later schizophrenia: A review. Addiction 2004;99:425-30.

102. Fergusson DM, Horwood LJ, Northstone K. Maternal use of cannabis and pregnancy outcome. BJOG 2002;109:21-7.

103. Zuckerman B, Frank DA, Hingson R, et al. Effects of maternal marijuana and cocaine use on fetal growth. N Engl J Med 1989;320:762-8.

104. Fried PA, Watkinson B, Willan A. Marijuana use during pregnancy and

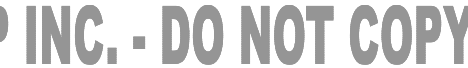

decreased length of gestation. Am J Obstet Gynecol 1984;150:23-7.

105. Gibson GT, Baghurst PA, Colley DP. Maternal alcohol, tobacco and cannabis consumption and the outcome of pregnancy. Aust NZ J Obstet Gynaecol 1983;23:15-9.

106. Witter FR, Niebyl JR. Marijuana use in pregnancy and pregnancy outcome. Am J Perinatol 1990;7:36-8.

107. Scragg RK, Mitchell EA, Ford RP, Thompson JM, Taylor BJ, Stewart AW. Maternal cannabis use in the sudden death syndrome. Acta Paediatr 2001;90:57-60.

108. Sidney S, Beck JE, Tekawa IS, Quesenberry CP, Friedman GD. Marijuana use and mortality. Am J Public Health 1997;87:585-90.

109. Disdier P, Granel B, Serratrice J, et al. Cannabis arteritis revisited ten new case reports. Angiology 2001;52:1-5.

110. Ducasse E, Chevalier J, Dasnoy D, Speziale F, Fiorani P, Puppinck P. Popliteal artery entrapment associated with cannabis arteritis. Eur J Vasc Endovasc Surg 2004;27:327-32. 


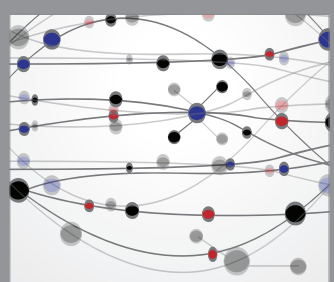

The Scientific World Journal
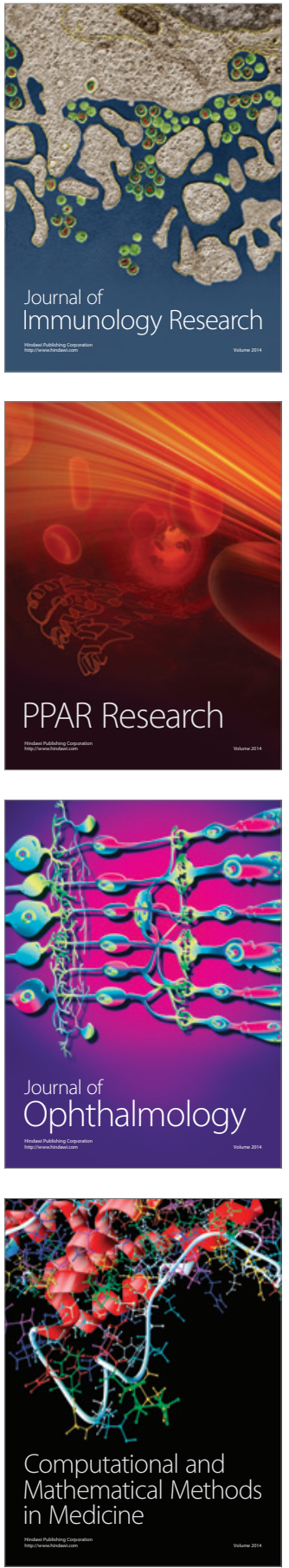

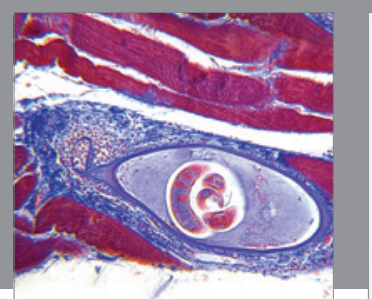

Gastroenterology Research and Practice

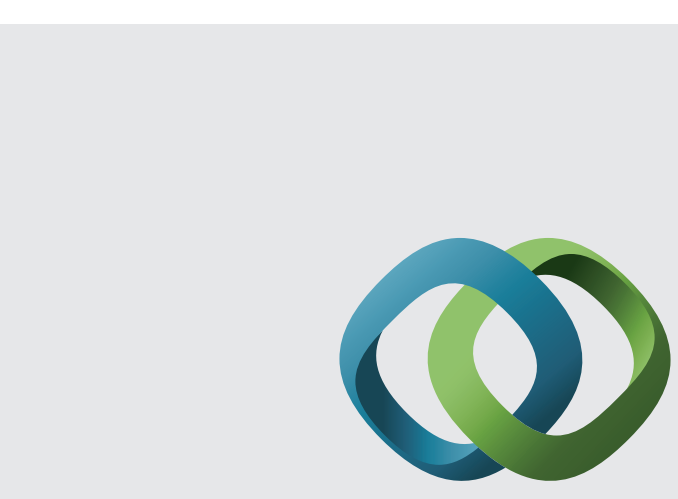

\section{Hindawi}

Submit your manuscripts at

http://www.hindawi.com
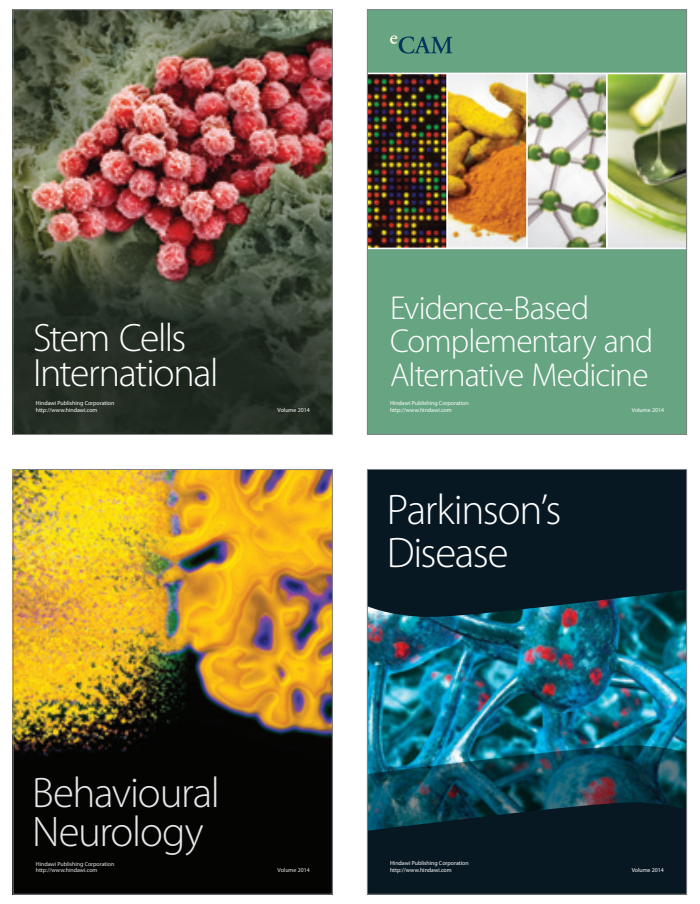
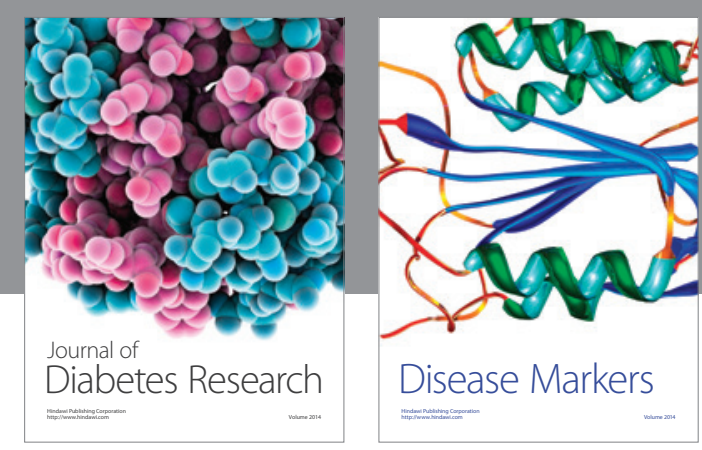

Disease Markers
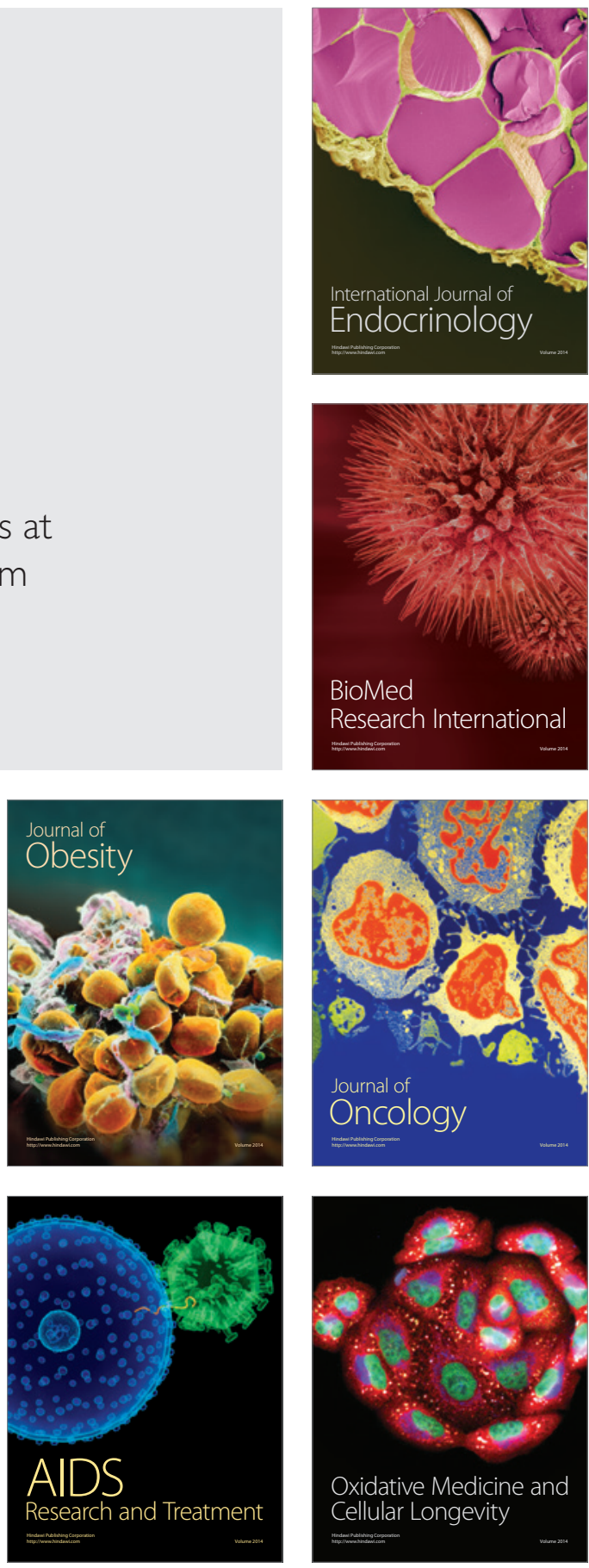